\title{
Towards constructing Paul's economic vision on poverty: The Jerusalem collection
}

Jeremy Punt

Faculty of Theology

University of Fort Hare

ALICE

E-mail: pjeremy@ufh.ac.za

\begin{abstract}
Towards constructing Paul's economic vision on poverty: The Jerusalem collection

Set against a broader discussion of Paul's economical perspectives, the emphasis of this article is on some of his directives concerning poverty. As much as the Pauline letters cannot be seen as a textbook for economic theory and practice, they offer no ready-made answers for addressing poverty, ancient or modern, either. It is in particular when addressing poverty - which he never did in abstract that Paul's considerable concern for the socio-economical situation of the communities he addressed becomes apparent. For Paul, evidently, poverty is not disconnected from other matters in the community such as righteousness and fellowship. These matters can easily be observed in Paul's motivation of the collection for the churches in Jerusalem. Some implications of Paul's treatment of poverty for theological thinking in this regard, are briefly explored.
\end{abstract}

\section{Introduction}

Christians often use the Bible when reflecting on issues such as poverty, particularly when its spread in our own country and around us on the African continent is so rampant and its influence so farreaching. It soon emerges when reading Paul on poverty that, on the one hand his perspectives on what we today would call the economy, should be understood according to the sensibilities of first-century economic views. But, on the other hand and as was also stressed in an earlier journal article (Punt, 2000:1-21) regarding some of Paul's views on work, his exhortations concerning economics were part of a larger complex of ideas. Without suggesting that Paul's emphasis on the collection for the 
Jerusalem church presents the full account of his concern about poverty in his letters, this article proceeds from the vantage point of Pauline perspectives and directives on the material want of the Jerusalem community, claiming that Paul's references to the collection should not be spiritualised. The primary purpose of the collection was clearly the attempt to relieve what appeared to have been a situation of desperate poverty in the Jerusalem church.

This is not in the first place an exegetical study, although it includes exegetical considerations. Proceeding from a cultural-critical interest, interacting with socio-historical evaluations of the first century economic context, reviewing various scholarly opinions and using a literary-critical reading of the Pauline letters, no easy application of Paul's sentiments to the evaluation of poverty today is suggested. Indeed, using the Pauline letters to construct a coherent and systematic response to contemporary economics, in one sense certainly goes beyond the pastoral and ecclesiocentric purpose of his letters, temporally and substantially. However, in another sense, such (post)modern construction of Paul's economic vision lies in the extention of that purpose. And after all, designating the formulation of such sentiments for today's economics, "Paul's vision" suggests an interactive relationship between the economic notions expressed in his letters, and today's world and its economic setting. In other words, this is not an attempt at ventriloquising Paul. The interaction between the ancient economy, Paul's concerns and our modern circumstances is exploited in this article, as an introductory investigation into the way in which Pauline sentiments might inform our thinking on the by now endemic poverty of large parts of Africa and the rest of the world.

\section{Paul on poverty: The collection ${ }^{1}$}

I suspect that the continual remembrance of the poor for which Paul expressed such resolve was not incidental to his theology, and that the scars he bore on his body were the measure of his commitment to that vision (Elliott, 1994:90).

The heading does not intend to suggest that the collection was only about alleviating poverty, as a form of Christian charity only. McKnight (1993:144) argues in his concise but detailed discussion on the collection that "[i]nvolved in Paul's collection were the credibility of his apostolic mission and the legitimacy of the Gentile mission (Gal. 2:110 ), the recognition of the priority of Israel in God's redemptive plan (Rom. 15:27), the goodwill of Christian communities (2 Cor. 8-9), as well as the need for individual Christians to trust in God to supply their needs if they were to give generously (2 Cor. 9)". These aspects might also have become Paul's task as part of an apostolic work arrangement (Everts, 1993:297). As explained below, different theological interpretations of the collection were likely to follow during the development of the Pauline ministry and beyond. 
Paul's repeated and (once) well-argued insistence on the need for churches to contribute to the alleviation of the poverty of the Jerusalem community stands in stark contrast to his disavowal of personal support. His emphasis on the collection confirms his own commitment to (as stressed by Elliott) and the early church's concern with care for the marginalised in the community: widows and orphans, the poor, the sick and elderly, and so on. Indeed, it can be argued that Paul's insistence that those who could, should work, enabled not only their own independence but also the potency to provide relieve to those who were in need (so e.g. Jones, 1984:224-225). Paul's preoccupation with a "collection"2 for the church in Jerusalem, which is not limited to two chapters in his second letter to the Corinthian church, ${ }^{3}$ requires further investigation. 4

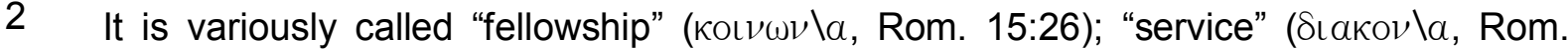
15:25, 31; 2 Corinthians 8:20; 9:1, 12, 13); "gift" ( $\chi$ V "generous gift" ( $€ € \lambda \circ \gamma \backslash \alpha, 2$ Cor. 9:5); "collection" ( $\lambda \circ \gamma \in \backslash \alpha, 1$ Cor. 16:1); "liberal gift"

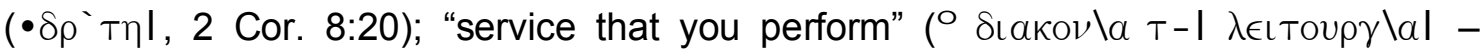
2 Cor. 9:12) by Paul. In 2 Corinthians 8:4 three different terms are used in the same sentence to refer to it: gift or privilege $\left(\chi \bigvee_{\rho l} l\right)$, sharing $(\kappa \circ \nu \omega \nu \backslash \alpha)$, and service

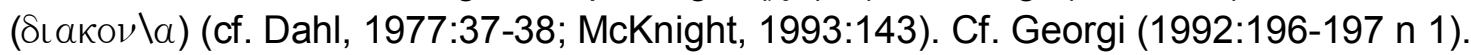

For Paul's personal sacrifice concerning the gathering and delivering the collection to Jerusalem, cf. e.g. Nürnberger (1978:164).

3 Cf. also Romans 15:26-27; 1 Corinthians 16:1-4; Galathians 2:10; and the allusion to it (cf. McKnight, 1993:143) in Galathians 6:6-10. It should be noted that although the collection is mentioned in Galathians and Romans, Paul requests support only in the Corinthian letters, especially in 2 Corinthians 8-9. Trobisch (1994:55-96; especially p. 87) provocatively argues that Paul selected and edited Romans, 1 and 2 Corinthians and Galatians for publication or circulation for the specific purpose of the Jerusalem collection.

Although very little evidence for the collection can be gained directly from Acts (except maybe 24:17), McKnight is at pains to point out that Paul's concern for the collection is borne out by the Acts-narrative (1993:143-144). Everts (1993:297) is less optimistic about Acts providing supportive material regarding the collection. Although in Acts 11:29-30 mention is made of concern expressed and action taken to relieve the need of the Judean Christians, Acts 15 (Paul's meeting with the Jerusalem apostles) and Acts 21 (probably about Paul's trip to Jerusalem) fail to mention the collection. Cf. also Georgi (1992:58-61) on the interconnectedness of Paul's own interests and personal fate with the collection, and the criticism this apparently evoked in the Corinthian church.

4 Cf. Georgi (1992:viii-ix) who finds the discrepancy between the importance of the collection in Paul's letters and the absence of its study by scholars alarming. His 1992book - a translation with "major differences" (Georgi, 1992:x) compared to the earlier German version of 1965 - is apart from Nickle's (1966) and Betz's (1985) studies the only comprehensive study on the collection. References to earlier studies by Holl, Munck, Franklin on the collection can be found in Georgi's bibliography. 
The most elaborate treatment of the collection is, however, found in 2 Corinthians 8 and 9. Paul's insistence on the collection for the saints in Jerusalem goes beyond that particular matter to include general concerns such as "the need for generosity (2 Cor. 8:12; 9:5-11), the goal of equality (2 Cor. 8:13-15) and the need for careful administration of the funds (2 Cor. 8:18-21)" (McKnight, 1993:143).

Indeed, as Georgi (1992:82) summarises, "[t]he principles of representation, vicarious action, reciprocity, and shared destiny are tightly connected to the concept of a collection for Jerusalem and its conveyance".

Paul insisted upon some sort of internal auditing team 5 to accompany him with the collected money: "Paul is exceptionally careful to have others supervise the collection and do what is honorable by human standards" (Everts, 1993:298; cf. Dahl, 1977:32 on 2 Cor. 8:20-21). In 2 Corinthians 8:18-22 mention is made of two (anonymous) people who were to accompany the collected money which had to be delivered to Jerusalem. "Swindle and embezzlement were not the only possible issues; Paul might also be compared to a money-greedy manipulator, or even simply derided for travelling around with money instead of the gospel" (Georgi, 1992:74).

These two persons were probably not, however, primarily appointed to manage the collection or its distribution. Their task was most likely apologetic: to, as competent preachers and theologians, explain to the various communities the purpose and reasoning behind Paul's collection tour and the presence of the money (Georgi, 1992:74).

\subsection{Spiritualising wealth?}

We find no such judgements [harsh pronouncements about wealth and its dangers] in Paul's letters. ... Paul neither condemns wealth nor glorifies its renunciation (Dahl, 1977:22-23).

As Paul never treated wealth and poverty as abstract topics in his letters as pointed out by Dahl, the temptation to spiritualise his references to these matters 6 is typically balanced by the argument that Paul was relatively unconcerned with riches and even less with poverty. ${ }^{7}$ So, in the

5 This was in line with the traditional prescriptions, too, as found in Deuteronomy 19:15 (cf. Nürnberger, 1978:165).

6 Such spiritualising of references to wealth and poverty is also found in treatments of the Gospels (cf. Birch \& Rasmussen, 1978:9).

7 Reasons offered for Paul's perceived disinterestedness would typically range from his eschatological-apocalyptic concern (e.g. Schrage, 1988:231; however, cf. the warnings of e.g. Georgi, 1991:102, Nürnberger, 1978:170), through the argument that early 
words of Schrage (1988:232), we learn that "[o]f course, alleviation of social problems is not the real purpose, but the communion of the body of Christ has an ethical and social dimension". Schmidt argues that Paul consistently spiritualises riches and wealth by using these and related terms to describe Christian spirituality and events related to it. Schmidt (1993:826) posits that very few people in the first century were poor in terms of no means of a livelihood, and that for Paul "poverty per se" was "not a concern". The poor in Jerusalem might refer to a situation of "economic deprivation", but then again it might be nothing more than "a self-designation of the Jews" who are "longing for the spiritual riches of salvation" (emphasis in original).

Suffice it to mention that it would probably be more accurate to note how integrally Paul sees financial matters to be related to spirituality. 8 In this regard Philippians 4:10-20 is especially noteworthy. Georgi $(1992: 64,66)$ notes how Paul applies the "highly spiritualized language of cultic piety" to a monetary gift. He argues that this passage could be seen as the "exegetical model"9 for interpreting Paul's statements about the collection.

Paul never glorifies poverty or the lack of sufficient material resources. As much as Paul's preference for sexual celibacy was driven by

Christians were structurally prisoners of the system(s) of the time, to claims that Paul's attention were to (individual) spiritual matters. Scholars often almost subconsciously propagate Paul's illusory silence on social matters; e.g., cf. Sider (1977:182) "Why have missionaries so often taught Romans but not Amos to new converts in poor lands". But cf. Elliott's (1994:93-230; 1997:371-89) rereadings of Paul, and Romans in particular (cf. also Georgi, 1991:81-104).

8 Cf. also e.g. Haan (1988:70) who stresses that Paul did not accept their assistance for "pure economic" considerations. "This economic traffic does not exist for its own sake. It is a spiritual experience. ... The support of Paul was in fact a pleasing sacrifice to God himself". And Nürnberger (1978:166) refers to the "investment of love in terms of money": eliminating or lessening the material want of others compels them to extend gratitude towards God, for the gift but also for the divine inducement of the gift. Georgi (1992:104) stresses that "Paul sees the collection for Jerusalem in a worldwide perspective ... a worldwide worship service, set in motion by God himself and proceeding in his own honor, for the increase of his power of grace" - in fact, Paul succeeds in historising the "mystical theme of spiritual worship" (Georgi, 1992:105). Georgi (1992:109) also notes that the collection "constitutes the tangible expression" of God's new creation, "the eschatological people of God" who are "covenanted with Jews and Gentiles alike". Indeed, "Paul's reflections on money are intimately related to central theological issues and interwoven with his life and the lives of his congregations" (Georgi, 1992:141).

9 Georgi (1992:66-67) argues that the note of thanks to the Philippians and the texts about the collection were written more or less at the same time, and that the issues discussed are "more or less the same". There are also similarities in "style, terminology, content and religio-historical detail" between these texts. 
usefulness to the benefit of extending God's reign on earth (1 Cor. 7:32 but cf. the rest of 1 Cor. 7 and especially 1 Cor. 7:2-6), his often selfinduced deprivation ${ }^{10}$ was perceived to be in direct service to the gospel (Phil. 4:11). Paul regarded the command to become poor for the sake of others as "the powerful initiative of free love which is willing to go the whole way" (Nürnberger, 1978:166).

\subsection{On the purpose of the collection}

As the sowing/reaping metaphor shows, Paul regards giving as a theologically significant activity (Everts, 1993:299).

One of the most important observations about the collection is to note its interconnectedness to and centrality within Pauline thought and practice: "... a close relationship between the collection, its establishment, and its organizational structure, on the one hand, with Paul's missionary thinking and strategy on the other" (Georgi, 1992:19, with reference to Munck).

The collection therefore served the purpose of legitimising Paul's mission to the Gentiles as illustrated by Galathians 2:10, while it established a vital link to the Jerusalem church and aimed at the unity of and equality within the body of Christ.

Everts (1993:297) mentions two possible antecedents for the collection temple tax and a votive offering - adding that "Paul gets many of his ideas about money from Judaism and applies those ideas in the churches he serves". Paul saw the collection as his "sacrificial offering to the Jerusalem community" (McKnight, 1993:143, referring to Hill). Georgi (1992:148-149) argues how and why Paul is careful not to describe the collection in terms which might be linked to "tax", "pilgrimage" and "debt and obligation".11

10 However, not all of Paul's self-sacrifice can be ascribed to "purely altruistic motives", in view of the emphasis in his letters on his "honour" or "fame", "reward" or "benefit", "glory" or "crown" (Nürnberger, 1978:169-170). Nürnberger qualifies this argument, viz that "the reward he receives and hopes for is identical with the success of the Gospel he preaches". This means that, ultimately, Paul's personal agenda is left out of consideration all together.

11 One should be careful not to make too much of the perceived "reticence" of Paul in employing "the language of the market economy". This is apparently evidenced by some in Paul's avoiding any reference to the collection money as "tax", to debts and obligations (except for Rom. 15:27), and a "negative attitude toward the concept of self and toward the adoration of the private, privatization, and private property", although he "knew the vocabulary of business language" (Georgi, 1992:148-149). Cf. Pathrapankal (1995:1005). 
Before considering the broader setting of the collection for Jerusalem, it might be helpful to note a number of possible reasons for Paul's insistence on and the importance he attributed to the collection:

\subsubsection{Helping the poor}

Concern for the poor was a dominant element in both Jewish and Christian piety (Everts, 1993:299).

A very common understanding of the collection sees it as Christian charity, a typical way to address poverty in the early church. "It is also an act of social welfare in an economic emergency" (Schrage, 1988:231). This ties in with Paul's insistence on showing compassion (Rom. 12:13; 1 Cor. 13; 2 Cor. 5:14; Gal. 5:6, 14; 6:10), which should be seen in the broader context of Jewish insistence on deeds of mercy (e.g. Ex. 23:11, Deut. 14:28-29; 24:19-22), Jesus' teachings (e.g. Mat. 6:2-4; 11:2-6; Luk. $6: 20-21$ ), and the earliest church's community life (e.g. Ac. $2: 43-47 ; 4: 32-$ $37 ; 6: 1-7)$. The call for compassion is representative of the love of God, as found by the Gentiles in Christ (2 Cor. 8:8-9, 19; 9:12-15). Poverty will be alleviated in the church by creating "equality"12 (2 Cor. 8:13-14) (McKnight, 1993:145).

Paul's argument is that generous giving is "a sign of grace (charis) and a ministry (diakonia) of the church" (Everts, 1993:299). Contributions to the collection will demonstrate the genuine love of the Corinthian Christians; in short, they will be imitating the love of Christ (2 Cor. 8:1-15).

\subsubsection{Uniting the church}

Going beyond concern for the poor, Paul's motives with the collection included his emphasis on unity within the church, attempting to unite the Gentile Christians in Diaspora and Jewish Christians in Judea. In line with the argument in Romans 9-11, Paul's insistence on unity concerned the "singularity of the gospel, the organic unity of the church, and the temporal priority of the Jewish people in God's redemptive plan". The exhortation to give voluntarily (1 Cor. 16:1; 2 Cor. 8:3, 8, 11-12; 9:1-5) and generously (2 Cor. $8: 2-4 ; 9: 6-15$ ) will ensure that the spiritual debt to

12 Georgi $(1992: 85,89)$ notes that $\Delta{ }^{`} T \eta$ l (equity or equality) was closely linked to -

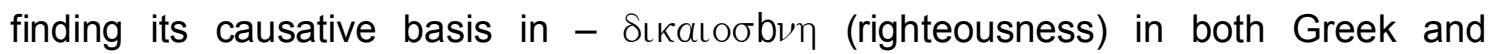
Hellenistic thought. ' $3{ }^{\prime} \mathrm{T} 0 \mathrm{l}$ occurs twice in 2 Corinthians 8:13-14 and nowhere else in the Pauline documents (Georgi, 1992:84-85). 
the "mother church" (Ac. 24:17) is acknowledged (Rom. 15:27)13 (McKnight, 1993:145; cf. Georgi, 1992:19, referring to Franklin).

Similarly, Dahl (1977:31) argues that the alleviating of economic need in the Jerusalem community was not "the element which weighed most heavily on Paul", but that "the gift proves the reality of the love which binds all Christians together"14. Moreover, the gift was in response to the apostolic agreement which required Paul to "remember15 the poor" (Gal. 2:10).

When Paul refers to the collection as $\chi \mathrm{Vpl}$ ( 1 Cor. 16:3), ${ }^{16}$ the notion of reciprocity is once again present. A gift is bestowed but with a sense of obligation towards the one receiving it, and in order to advance close association with a view towards further cooperation and mutual benefits in future (Georgi, 1992:54).

\subsubsection{Substitute for Jewish initiation rites}

The collection can be interpreted as the Gentile equivalent, and in lieu, of Jewish sacrifices and circumcision in particular. The monetary and other gifts to the Jerusalem community indicated Gentile association with and fidelity to the covenant with Abraham (e.g. Sir. 29:12, 40:24; Tob. 4:1011, 12:9, 14:11; Ac. 10:2, 35). The collected money and gifts would acknowledge Gentile commitment to Israel and the Law, and

13 As McKnight (1993) suggests, the collection may have been perceived by Paul as the crowning achievement of the first (and eventually, the only completed) part of his ministry (the "fruit" and "seal" of that effort, Rom. 15:23-24, 28). The Jerusalem community might, however, have seen the collection as the obligation of the Gentile communities as "expression of their dependence upon the founding churches" (McKnight, 1993:145), or at least within a reciprocal relationship (cf. Everts, 1993:299).

14 And this unity went beyond geographical distance and personal unfamiliarity, ethnic and cultural barriers between Jewish and "Gentile" Christians, tensions regarding the status of apostles (e.g. Gal. 2:6; 1 Cor. 2; 2 Cor. 11), sincere theological disagreements and conflicts (e.g. Gal. 2:11 ff; 2 Cor. 10 ff; Phil. 3) (cf. Nürnberger, 1978:163).

15 Cf. Pathrapankal (1995:1005-1009) on $\mu \nu \eta \mu o \nu o \nu \in b \in \iota \nu$ "remembering" throughout the Bible is more than "a psychological exercise of calling to memory something of the past, but an act of mind and will, out of which a corresponding action follows".

16 The importance of seeing the collection as $\chi V_{p l} \mathrm{l}$ is intensified when it is realised that the Macedonian churches were probably equally adversely affected by poverty $(2$ Cor. 8:2) - " $\chi \bigvee \mathrm{V}$ l becomes the very leitmotif' of 2 Corinthians 8 and 9 (Georgi, 1992:72; cf. 82-83). Participation was seen by Paul as part of the charismata, all of which he took as being "by nature active" (Georgi, 1992:82). Georgi also refers to the connection between $\chi \mathrm{V}_{\rho l} \mathrm{l}$ and $\epsilon € \ell_{o \gamma} \mathrm{la}_{\alpha}$ ("the confirmation or the establishment of a communal relationship, not just ... a prayerful wish or thanks"). 
acknowledge Jewish salvation-historical privilege ${ }^{17}$ (McKnight, 1993:145146).

The collection has also been interpreted in the past as the obligation of Gentiles which corresponded to the traditional Jewish temple tax ${ }^{18}$ (Holl, referred to in Georgi, 1992:17).

\subsubsection{Eschatological inspiration}

Paul seems to suggest in Romans 11:11-24 that the conversion of the Jews to the Messiah, Jesus Christ, was dependent on the salvation of the Gentiles. With the Gentile collection brought to Jerusalem the prophecy (Is. 2:2-4; 60:6-7, 11) will be fulfilled, resulting in an "eschatological provocation" aimed at stimulating Jewish belief in Jesus Christ as the Messiah (cf. 2 Cor. 9:10, alluding to Is. 55:10; 2 Cor. 9:1112) (McKnight, 1993:146; cf. Georgi, 1992:18, quoting Hall). The biggest problem with this explanation is that Paul himself never explicitly mentions this as the reason for the collection (cf. Everts, 1993:299).

Georgi takes the eschatological argument in a different direction when he suggests that the notion of the "poor" in Jerusalem underwent some development in the Pauline letters. Early on the "poor" is an eschatological concept referring to God's chosen if oppressed and marginalised people, "the future co-rulers of God". However, by the time he wrote Romans, the "poor" has become a "sociological designation" and the self-understanding of the Jerusalem believers is no longer taken into account. The church's importance is now redefined, in terms of "its relationship to the worldwide missionary activity and the worldwide church".19 And in this way, the collection becomes both the confirmation and promise of the growing community of Christ (Georgi, 1992:33-34, 114-121).

An oft heard suggestion is that possessions and money were in Paul's eyes of "little concern" and "trivial" because of the nearness of the new age and because material concerns belong to the old age (e.g. Dahl, 1977:24). However, although Paul expected the imminent and

17 Although, of course, the Gentiles have become "the forerunners of liberated humanity, the witnesses to the Jews to the presence of God's eschatological salvation - not the other way round" (Georgi, 1992:101).

18 Although Georgi (1992:53) cautions that $\lambda \circ \gamma \in \mid \alpha$ in 1 Corinthians $16: 3$ does not refer to "a tax" as Paul did not have a permanent injunction in mind.

19 For the provocative nature of this step, and Paul's awareness of the provocation, cf. Georgi (1992:117-120). 
apocalyptic return of Christ, "worldly" matters never ceased in importance for him but were recast in service to the dawning new age. Economic matters were not "trivial" for Paul, but in fact like all other matters, contingent upon and therefore relative to the coming reign of God (cf. Dahl, 1977:25). ${ }^{20}$ And, it should be added, his eschatological expectation rather served to intensify than trivialise Paul's social concerns (cf. Georgi, 1992:102). ${ }^{21}$

To summarise: It is not uncommon to argue that Paul's purpose with the collection might have included various elements, to varying degrees, of the above-mentioned possibilities. A more integrated explanation of Paul's purpose with the collection will allow one to perceive the interconnectedness of the "eschatological status of the Jerusalem congregation" and the need "to assist that congregation both morally and economically", grounded in the belief of the unity of Christ's body and in the hope of his impending return (Georgi, 1992:42). As the collection gained a momentum of its own,22 it moved away from its "original contractual purpose" to a "paradigm for ecumenical communal exchange in the form of a financial communication", "a demonstration of the interplay of divine gift and human gratitude" (Georgi, 1992:152).

\subsection{Result of the collection}

Paul's own letters give no indication whether the collection was ever presented to the Jerusalem church or its effects. It is possible to infer from the account in Acts 21:17-26 that the collection was well received. Scholars have argued, to the contrary, that the collection failed to live up to Paul's expectations: "The saints remained poor, the act of charity notwithstanding; the tension between Jewish Christians and Gentile Christians continued; and the conversion of Israel never took place" (McKnight, 1993:146).

20 Paul clearly did not subscribe to the radical denunciation of temporal economy as found in Apocalypticism (where state power and wealth, i. e. economic and political strength, meant corruption and sinfulness) or Gnosticism, nor to the appreciation of "performance- and market-oriented society" as found in Jewish missionary wisdom (Georgi, 1992:144, 214 n 8-9).

21 Contra Hengel (1974:39-41) who argues for the "eschatological relativization of property" in Paul.

22 In 2 Corinthians 8 Paul is to be found describing the collection as if he was only a witness to the event. It appears that at some stage in the process of gathering the collection, it developed its own momentum. "This is why Paul suddenly felt deprived of his founder rights and transformed into a mere spectator". All the same, this very momentum generated by the collection-efforts was what guaranteed its success in Paul's opinion (Georgi, 1992:72, 105). 
Employing an argument of silence, McKnight is optimistic that the collection "would have" accomplished Paul's goals of, at least, alleviating some of the poverty of the Jerusalem church and mollifying the tension between Gentile and Jewish (Jerusalem) Christians to some extent. ${ }^{23}$

\section{Righteousness, fellowship and sharing}

In the collection, a cycle of grace occurs in which money is the expression and means of a process that moves human hearts and draws people together (Georgi, 1992:152).

Evaluating Pauline statements on poverty and its alleviation as they emerge from his letters and the references to the collection in particular, shows that more than (Christian) charity is involved. It is interesting to note that Paul used $\kappa o L \nu \omega \nu \backslash \alpha$, often referring to fellowship, to express "generosity or liberality" in financial terms (2 Cor. 8:4; Phil. 1:5; Philem. $6)$.

The ideas of the circulation of money and of economic growth have been exchanged for the circulation and growth of the grace of God among people, even the growth of God self for the benefit of all humans (Georgi, 1992:153-154).

At times a "concrete form of this generosity" is signified by both noun and verb, in the sense of a "gift", "contribution" (e.g. Phil. 4:15; Gal. 6:6) or the Jerusalem collection (cf. Rom. 15:26) (O’Brien, 1993:294).

In Paul's understanding of money the spiritual and material aspects of giving and receiving are closely related ... Requests for money are rooted in partnership in the gospel; one gives out of thankfulness for the spiritual benefits received (Everts, 1993:299).

Similarly, scholars such as Dahl (1977:30-31) and Georgi (1992:82-83) point out that generosity was listed by Paul as a "spiritual gift". Paul emphasised the "giver's attitude" - the joy and the love expressed in the gifts - and not so much the financial aspects involved in generosity.

23 Cf. Georgi's (1992:125-126) argument that the collection, ironically, ended up paying for cultic services with Paul paying for the expenses to have the four destitute Nazarites released. Still, this both allowed for the Jerusalem church to accept the collected money, and to defend Paul against charges of enmity towards the Torah.

Tragically, if Georgi's reading of the events in Jerusalem is accurate, this eventually led to Paul's imprisonment through a misunderstandng that Paul desecrated the temple punishable by death penalty under Jewish law - by bringing an uncircumcised Gentile, Trophimus, into the temple. Paul went to Rome, and probably met his death there (Georgi, 1992:126-127). Pathrapankal (1995:1013) laments that the "relief fund" failed to impress the Jerusalem church and its leadership. 
"Money becomes more than just money within the Christian church; it attains an almost sacramental significance: 'A visible sign of an invisible grace'”.24

Paul conflates the notion of the righteousness of God with the idea that true human compassion and generosity finds its origin in God25 (2 Cor. 9:5-15). "God's righteousness is the origin of human righteousness, but the latter is allowed to reflect and represent the former in full". With resourceful use of Psalm 111 the "righteous one" to whom Paul refers is not God, but the pious person, merciful and compassionate. Such righteousness 26 is therefore not in the first place a "quality", "virtue" or "correct moral behaviour" of a human being, but could also refer to someone being "integrated into the sphere of divine righteousness" and therefore acting towards the community in accordance with God's covenant with humanity. Righteousness forms the point of departure for the restructuring of "true community as a model society", which becomes at the same time a more "reasonable" society - and, the initiating model society being the church (Georgi, 1992:98-99; 158-161).

This justifying grace creates wise and reasonable, in a word good, praxis, in which personhood and the identity of persons is formed through relatedness and concern for others. ... It is giving instead of gaining, thanks instead of interest, confidence instead of credit, trust instead of security, community instead of market, spiritual worship instead of temple cult, charisma instead of property. This praxis avoids the power that grows out of fear and that leads to exploitation and violence. Instead, this praxis affirms the power of weakness and poverty because such power allows for authentic engagement, reliable yield, and true growth. ... This praxis will instigate and

24 Cf. Verhey (1984:119): "[l]t is also the case that generosity and hospitality are "nearly sacramental' themselves (Phil. 4:18), a material sign of a spiritual grace". Cf. Dahl (1977:35).

25 In the words of Nürnberger (1978:164): "It is remarkable that Paul derives his exhortation to give freely from the very centre of his Gospel: Christ did not give this or that; he gave himself!". As much as "creation and created life originate in and are maintained by grace", "[t]he sharing initiated by the collection "becomes the manifestation of the body of Christ"” (Georgi, 1992:153-154).

26 It is important to note that whereas in the Hellenistic world equity and equality were synonyms for righteousness and justice as the "basis and moving force of society", for Paul righteousness is the basis of equality (Georgi, 1992:154-155). Cf. Sider (1977:101-104) on the right to property being explicitly and implicitly affirmed in Scripture, although it is not an absolute right; Georgi (1992:160-161) claims that the concepts of "private property and private ownership find in Paul no place at all". For the importance of "righteousness" and related terms for economics in the Hellenistic world, cf. Xenophon's Oeconomicus (Georgi, 1992:145). 
invigorate truly humane, namely relational, ethical, and consciously political elements in the economy, and will make them transparent (Georgi, 1992:160).

The Pauline bottom line is: Human acts of compassion and generosity are not separate or independent from divine action.

With the collection Paul is clearly addressing economic issues on more than the individual level. Although it can hardly be claimed that Paul introduced an economic system characterised by justice, or an economic system at all, his concerns reached beyond the confines of economic justice to individuals.

The idea that in Christianity only the right attitude counts, while structures do not matter, finds no support in the Bible! Paul is emphatic that attitudes alone carry no weight and he presses for formal institutionalised processes with concrete aims, and involving particular agents and carriers (Nürnberger, 1978:164).

The importance of the community is underlined in Dahl's comment $(1977: 24)$ that "Paul never looks at an individual's relationship to money in isolation" as he factors in three "decisive" issues ("eschatology, the church and his own situation as apostle"). ${ }^{27}$ "Increase of wealth for him [Paul] needs to be common wealth. ... The money involved becomes a social force, a gift from community to community. ... This sharing becomes a manifestation of the body of Christ" (Georgi, 1992:153). ${ }^{28}$

Paul's insistence on "equality" ( $\left.\Delta \Phi^{\prime} \tau \eta \mathrm{l}\right)$ within the community (church) is

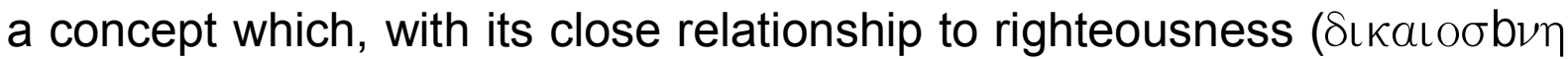
(cf. Van Wyk, 1978:212), comes to stand next to $\chi V_{p \iota l}{ }^{29}{ }^{\prime} I \sigma^{`} \tau \eta l$

27 Yet, Paul emphasised the importance of rational thought: appealing to reason he urges the Corinthians on to show compassion and give generously (2 Cor. 9:5-7). "For believers, freedom means liberation from self. True rationality and free decision-making become possible only subsequent to this liberation" (Georgi, 1992:95, 97-98).

28 Paul's premise was the biblical prohibition of interest (cf. Ex. 22:24, Lev. 25:36-37).

29 Nürnberger (1978:167) contends that Paul derives the idea of equality from the Old Testament. Cf. also Verhey (1984:120); Gonzáles (1990:86) who notes that Paul's argument is corroborated by Exodus 16:18 (manna, the eschatological symbol, but also illustrative of "equality, sharing, freedom from hoarding and dependence on God"); cf. Haan (1988:61-65). In the Greco-Roman world equality was often frowned upon; cf. Cicero who regarded it as a "terrible evil" (Schrage, 1988:231). Equality did not mean that everyone has "exactly the same as everyone else", nor did it imply communal ownership of property and/or the means of production (not even in Ac. 2:44; 4:32). Because poverty is not "static", measures must be put in place to deal with poverty, such as the Jubilee. God sees and treats all the children of Israel as equal, and Paul reinterprets this idea "in terms of the self-giving love of Christ". For the relationship 
becomes a divine principle and is now the fountainhead of giving and receiving. This implies that "the principles of performance and achievement fall aside, and with them all comparing, measuring, and judging" (Georgi, 1992:89; cf. :155).

'I $\sigma^{`} T \eta \mathrm{I}$ is for Paul a divine force which makes humans equal, ${ }^{30}$ from "equity (as divine potency of efficaciousness) to equality (as human experience, legal, social, and economic reality)" (Georgi, 1992:155, summarising 2 Cor. 8:13-14). Paul's emphasis is on the "allencompassing movement of grace", through which righteousness and equality becomes possible, which is always to be found in its divine origin. "That means that poor Christians should not only be cared for while they remain poor, but their poverty must be eradicated with the eye on economic equality between Christians" (cf. Ac. 4:32,34-35) (Van Wyk, 1978:212).

But this movement extends beyond Christian communities: "Universal poverty and universal redemption are presupposed by Paul. Global equalization is in view"31 (Georgi, 1992:156).

Georgi contends that for Paul the crucial economic issue of the collection was the "ability to respect the dignity and integrity of the poor, their gift and witness to society". The poor of Jerusalem are not regarded as "social and economic debris" but representative of the "spiritual things" 32

between $\tau b_{X} \eta$ (and connotations of the economic well-being of the community) and $\chi V_{\rho l} \mathrm{l}$, cf. Georgi (1992:151-152). Pathrapankal (1995:1005) sees Paul's references to the collection with terms such as $\chi \bigvee \rho \iota l, \delta\llcorner\alpha \kappa o \nu \backslash \alpha$, and $\kappa o \iota \nu \omega \nu \backslash \alpha$ as an indication that his concern with it was primarily "solidarity" with the poor.

30 And, of course, money was and still is the great equaliser (cf. Georgi, 1992:154-155).

31 Contrary to Schrage (1988:232): "Paul obviously did not espouse or undertake social action for the benefit of unbelievers on the basis of the fundamentally unrestricted law of love" (although Schrage admits that Paul treated the unconverted Onesimus according to "the ethics and praxis of Christian solidarity" and that Paul's appeal for Onesimus' freedom "has real consequences not only within the community but also in the world"; Schrage, 1988:234). As much as "money connects with the future" (Keynes), Paul's aim with the collection is connected to the future. Starting out as an attempt to assist the poor of Jerusalem as the "avant garde of God's new age" in (active) anticipation of this era, the collection became a more general eschatological paradigm, inducing "tangible utopian dimensions and aspects" (Georgi, 1992:158-159). Utopian scenarios have recently been much discussed - for a critique of orthodox theology's anti-utopian condemnation of liberation theology, cf. Hinkelammert $(1997: 31)$.

32 "Paul's argument about the exchange of the fleshly against the spiritual is taken from the rules of religious competition, more precisely, from the rules of the religious market, a rather important sector in the wider Hellenistic market economy. ... Paul gives the poor ones higher market value" (Georgi, 1992:163-164). 
they represent, the "main gift of that church to the rest of the churches" (Georgi, 1992:163-164). Coming perilously close to romanticising poverty in Paul's name by making poverty the cutting-edge of human life, Georgi $(1992: 164)$ contends that the poor "point to poverty as the basis for human and social existence", that the poor serve to remind and challenge others "who believe themselves to be removed from poverty".33 However, Georgi is convincing in claiming that according to Paul "the call to invest in the poor ones represents the central, not the peripheral, concern for the market society that wants to be truly economical, a society that really desires to invest in the future". Because, the poor in biblical terms "are not the rear guard of the past but the avant garde of the future" (Georgi, 1992:165).

Yet, there is no "communistic ideal in Paul's letters, not even of a voluntary consumers" communism as an expression of love. He does, however, mention the ideal of "economic equality" (Dahl, 1977:30; Hengel, 1974:35). Neither is another statement by Paul in 2 Corinthians 8:9 on Jesus putting his wealth aside and taking up poverty, to be considered as a proof text for ascetism, 34 requiring economic or other material sacrifices. "Poor" and "rich" here refers more probably to "the respective states of heavenly and earthly existence", and the text refers to "that event in which the heavenly dimension of life became human". In the end, Paul's statement is a universal assertion about the salvation wrought by God (Georgi, 1992:83).

"There is a pervading but quiet heroism which characterises Paul's attitude toward money; to use Paul's words: 'The love of Christ controls us.' (2 Cor. 5:14)" (Dahl, 1977:36). "[F]ar from being concerned simply to see that property rights are kept inviolable, Paul maintains that such institutions must take second place to the demands of the gospel and love" (Schrage, 1988:235).

33 Georgi (1992:164-165) also refers to the "potential or gift" "that is in human not-having, not-possessing". However, he does qualify it by referring to the ability of the poor to "make do"; that the poor points to the "redemptive engagement of Christ"; and, that the poor "call up the not-yet of society", challenging "the sterility of a rich society". Therefore, he argues, a community that reaches out to the "hopeless cases" is "clearly the more risk conscious, the more courageous, imaginative, and inventive".

34 Paul never advocates ascetism as he appreciates all that exists as the gift of God, and which people ought to enjoy to the full. This freedom and its enjoyment should, however, never lead to the injury of a fellow-Christian (Nürnberger, 1978:170). In the later Pauline tradition the goodness of the creation is emphasised by affirming God as

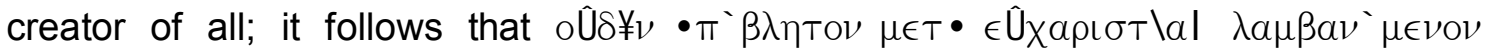
(nothing is to be neglected if received with thanksgiving) (1 Tm. 4:4). "It is not because food, clothes, and property are inherently evil that Christians today must lower their standard of living. It is because others are starving" (Sider, 1977:113). 
Georgi adds that money does not, from Paul's point of view, create but "it stimulates, facilitates, and sets in motion the process of thanksgiving". Such growth is "in the context of the return of divine grace", "in the context of shared righteousness, the mutual respect for equality and integrity" (Georgi, 1992:161). ${ }^{35}$ Money and market are creations of the community and should function as such: communal trust should back financial credit. "[T]he community has to remain above the market, all the more the international community above the international market. Accordingly, money and market have to remain expressions of the community's basic right and its manifestation in communal laws". This entails the equality of all, whether creditor or debtor (Georgi, 1992:161162).

\section{Concluding remarks}

It is tragic yet unavoidable that Pobee's (1993:397) characterisation of African identity should include a reference to Africa's bondage to "the grip of a culture of poverty". In view of this sad fact, however, "[i]f Biblical hermeneutics fails to address the issue of poverty in Africa, can it be said to be contextual?" (Magessa, 1997:33). Surely, to deal with poverty which surrounds us in a theologically adequate way, more is required than this brief foray into Pauline sentiments on poverty - but we have to start somewhere. 36 Paul's comments regarding the collection provide a launching pad for theological reflection on poverty that ultimately goes beyond material altruism, however important that itself may turn out to be in South Africa.

Paul certainly advocates active financial help to the poor, as charity. However, such assistance should never become a "conscience tranquilizer" (Johnson, 1989:26). In fact, charity should follow careful consideration as "faithful stewardship requires care in selecting those who are truly in need of charity" (North, 1974:221). Otherwise charity can become the "instrument of sin":

35 Money is never neutral, cold or indifferent. As intimate friend of the market, it easily become a law to itself and develop a life of its own. On the other hand, money is more than nominal value, buying and market power; it is also about social value and standing, social acceptability, and subjective feeling of value (Georgi, 1992:161-162).

36 And it is an urgent task for theology; cf. Éla (1994:137) "While people wallow in misery, we are centering our reflection and action on religious rites and customs!"; Hays (1996:468): "[l]maginative obedience to God will require of us a sharing of possessions far more radical than the church has ordinarily supposed". Nürnberger (1994:41-58) makes a number of useful remarks on the need to devise a sound economic vision for $\mathrm{SA}$, and the role the church can play in an economic restructuring process. Dickinson (1983:127-147) sees "theological and ethical reflection" on these issues as one of the ways in which the church shows solidarity with the poor. 
The recipient is humiliated by his [sic] dependency. His spiritual indebtedness to the donor is added to his material poverty and his situation becomes worse than it was before. The donor derives great satisfaction from his superior position. The moral benefits of his deeds are added to his material wealth. Giving often leads to a deepening gulf between unequals instead of really bridging the gap (Nürnberger, 1978:168).

It is for this reason that Paul's appeal for generous giving should be matched to his understanding that equality of all in the community is the aim.

Employing Pauline perspectives in deliberating on the current economic woes of the world, is not a magic wand or "ten-easy-steps" to ensure an equitable and just (global and local) economic system. Indeed, Paul did not provide us with a blueprint for a new economic order, on how to structurally adjust economic systems globally to eradicate poverty and ensure equality. ${ }^{37}$ However, two things need to be noted in this regard.

- One, Paul's pastoral and ecclesiocentric hermeneutics was dynamic in nature and creative in style, characterised by freedom and he therefore required his followers to follow his style, and not necessarily his choices (e.g. Lategan, 1990:318-328 on Paul's ethics).

- And two, on the one hand, Paul addressed the Christians of his churches, a small minority in the first century, at a time when most people had no say in political and economic matters on structural level (cf. Hengel, 1974:41). But on the other hand, Paul's letters are evidence - as soon as the traditional (Reformational) legacy of understanding Paul allows for other interpretations as well38 - that Paul's advice and encouragement were often challenging to the status quo, on religious, political, economic and cultural levels. To stay quiet about economics, about wealth, and about poverty in South Africa (and Africa at large) today, will be very un-Pauline. Using Pauline sentiments for deliberating economics today will probably put more than one thorn in a wide body of flesh (2 Cor. 12:7) - one's own included - but that will be quite Pauline!

37 Georgi (1992:146), however, contends that "[t]he Pauline correspondence increasingly became a primary source for my understanding of the ancient world". And, he adds, "[h]ow one understands the origin of the Greco-Roman economy ... has direct bearing on how one understands our own today" (Georgi, 1992:146).

38 And in any case, in Georgi's (1992:142) words, "the church needs to begin to reflect on justification by Christ in its financial offices as well as in its pulpits". 
[O]ur gospel must respond to the problems of poverty and oppression; we must not pretend that poverty does not exist or claim that it arises primarily for different reasons [than oppressive mechanisms in society]. This response is found above all in praxis ... As Paul demonstrates in Galatians, not only the fullness, but the authenticity of the gospel here hangs in the balance. Justification by faith must come to expression in 'good works', a commitment to the poor (Gal. 2:9-10; 5:6). If this does not happen, we are living and preaching 'another gospel' (1:6-9) (Hanks, 1983:60).

Paul never justifies and certainly nowhere glorifies poverty. On the other hand, it would not be unreasonable to place Paul firmly in line with the biblical and reformed protestant 39 notion that God is on the side of the poor (Van Wyk, 1978:212), or to use the more contemporary phrase, has a preferential option for the poor.40 Concerning the collection for Jerusalem, then, one can agree with Pathrapankal (1995:1017) that it included but went beyond charitable giving:

... the entire issue was a sharing of Christian fellowship and solidarity, and its message stands out as a permanent reminder to the church of all times and her theologians to commit themselves 41 to the task of liberating the people of God from all oppressive and dehumanizing structures in order to enable them to live a more human and dignified life.

Paul's insistence on both the need for the collection and the other churches' participation in it, becomes an effective symbol of liberation and empowerment of communities and its people.

In an era or culture of entitlement, the other important contribution of Paul on work should not be glossed over: "This underlying principle of independence and freedom, of providing the needs of individuals and the Christian community through hard work, is a prominent contribution of the apostle Paul" (Jones, 1984:224).

39 E.g., "Calvin can also exhort the Christians not to long to be rich, while he strongly urges the rich to live in modesty and not to oppress the poor" (Van Wyk, 1978:212).

40 Jobling (1993:101) argues that the biblical imperative is nowadays less in terms of "to the ends of the earth" and more in terms of "the preferential option for the poor".

41 Not that official or institutionalised religion has a good track record in this regard. Until now, it was more often folk religion or popular religion which challenged the hierarchical powers (Huizer, 1993:69-70). 
Paul required his churches, generally poor and under-resourced, to be economically active, ${ }^{42}$ as much as he expected them to be involved in alleviating poverty. One simple question seems to be: How should the Christian church of today with its huge levels of affluence and riches, with its political-ideological power, and its ability to influence political decision-makers, with world-wide religious organisations to its disposal, $\mathbf{4 3}$ today treat the growing global problem of poverty, especially in Africa? And how should it go about contributing to an alternative, positive economic dispensation?

The inadequate sense of economic benefaction to the wider community often found in churches, as well as the market-economy of modern society will probably require of Christian churches, the majority of which have a colonial-missionary background, not to try and deal with the ideal of eradicating the poverty endemic to Africa, including South Africa, on their own. In South Africa poverty is largely synonymous with being black (Isichei, 1995:3; cf. Pato, 1997:40), adding another complex dimension to any attempt to address poverty. Not only churches but the intended recipients of "financial loving-kindness" will not, in the absence of a benefaction-system which was well-developed in the first century, be able to replicate the material relationships and activities of the earliest Christian communities. But, the Christian community will have to be conscientised and will have to re-conceptualise their economic reality in Pauline style (Rom. 12:2), cognisant of his arguments about work and poverty.

\section{Bibliography}

BIRCH, B.C. \& RASMUSSEN, L. 1978. The Predicament of the Prosperous. Biblical Perspectives on Current Issues. Philadelphia : Westminster.

DAHL, N.A. 1977. Studies in Paul. Theology for the Early Christian Mission. Minneapolis : Augsburg.

DICKINSON, R.D.N. 1983. Poor, yet Making Many Rich. The Poor as Agents of Creative Justice. Geneva : WCC.

ÉLA, J. 1994. Christianity and Liberation in Africa. (In Gibellini, R., ed. Paths of African Theology. London : SCM. p. 136-153.)

ELLIOTT, N. 1994. Liberating Paul. The Justice of God and the Politics of the Apostle. Bible and Liberation. Maryknoll : Orbis.

42 How this will be achieved, has to be worked out in partnership between employers, employees, unemployed, and so on. Grasping merely for terms such as "productivity" might prove counterproductive (cf. Challenge, April 1999). Haan (1988:44) notes that "[m]odern economy suffers from the delusion of efficiency".

43 Of course some religious and church organisations have for many years been attending to poverty across the globe and projects such as "Bread for the World" and various other are active and operational. Cf. also Sider (1977:193-195). 
ELLIOTT, N. 1997. Figure and Ground in the Interpretation of Romans 9-11. (In Fowl, S.E., ed. The Theological Interpretation of Scripture. Classic and Contemporary Readings. Blackwell Readings in Modern Theology. Oxford : Blackwell. p. 371389.)

EVERTS, J.M. 1993. Financial Support. (In Hawthorne, G.F., Martin, R.P. \& Reid, D.G., eds. Dictionary of Paul and his Letters. Downers Grove : IVP. p. 295-300.)

GEORGI, D. 1991. Theocracy in Paul's Praxis and Theology. Trans. Green, D. Minneapolis : Fortress.

GEORGI, D. 1992. Remembering the Poor: The History of Paul's Collection for Jerusalem. Trans. Racz, I. Nashville : Abingdon.

GONZÁLES, J.L. 1990. Faith and Wealth. A History of Early Christian Ideas on the Origin, Significance, and Use of Money. San Francisco : HarperSanFrancisco.

HAAN, R. 1988. The Economics of Honour. Biblical Reflections on Money and Property. Trans. Forest-Flier, N. Geneva : WCC.

HANKS, T.D. 1983. God so Loved the Third World. The Bible, the Reformation, and Liberation Theologies: The Biblical Vocabulary of Oppression. Trans. Dekker, J.C. Maryknoll : Orbis.

HAYS, R.B. 1996. The Moral Vision of the New Testament: Community, Cross, New Creation. A Contemporary Introduction to New Testament Ethics. San Francisco : Harper.

HENGEL, M. 1974. Property and Riches in the Early Church. Aspects of a Social History of Early Christianity. Trans. Bowden, J. London : SCM.

HINKELAMMERT, F.J. 1997. Liberation Theology in the Economic and Social Context of Latin America: Economy and Theology, or the Irrationality of the Rationalized. (In Batstone, D. et al., eds. Liberation Theologies, Postmodernity, and the Americas. London \& New York : Routledge. p. 25-52.)

HUIZER, G. 1993. People's Movements and Global Elite Stategies. (In Reuver, M., Solms, F. \& Huizer, G., eds. Kampen, Geneva : Kok, WCC. p. 69-92.)

ISICHEI, E. 1995. A History of Christianity in Africa. From Antiquity to the Present. Grand Rapids, Lawrenceville : Eerdmans, Africa World Press.

JOBLING, D. 1993. Globalization in Biblical Studies / Biblical Studies in Globalization. Biblical Interpretation, 1(1): 96-110.

JOHNSON, G.S. 1989. Beyond Guilt and Powerlessness. Christian Response for Human Suffering. Minneapolis : Augsberg Fortress.

JONES, jr, A. 1984. Paul's Message of Freedom: What does it Mean to the Black Church. Valley Forge : Judson.

LATEGAN, B.C. 1990. Is Paul Developing a Specifically Christian Ethics in Galatia? (In Balch, D.L., Ferguson, E. \& Meeks, W.A., eds. Greeks, Romans and Christians. Essays in Honor of Abraham Malherbe. Minneapolis : Fortress. p. 318-328.)

MAGESSA, L. 1997. From Privatized to Popular Biblical Hermeneutics in Africa. (In Kinoti, H.W. \& Waliggo, J.M., eds. The Bible in African Christianity. Essays in Biblical Theology. African Christianity Series. Nairobi : Acton. p. 25-39.)

McKNIGHT, S. 1993. Collection for the Saints. (In Hawthorne, G.F., Martin, R.P. \& Reid, D.G., eds. Dictionary of Paul and his Letters. Downers Grove : IVP p. 143-147.)

NORTH, G. 1974. An Introduction to Christian Economics. A Chalcedon Study. Nutley : Craig. 
NÜRNBERGER, K. 1978. The Economics of Paul. (In Nürnberger, K., ed. Affluence, Poverty and the Word of God. An Interdisciplinary Study Program of the Missiological Institute Mapumulo. Durban : Lutheran Publishing House. p. 163171.)

NÜRNBERGER, K. 1994. An Economic Vision for South Africa. The Task of the Church in the Post Apartheid Economy. Pietermaritzburg : Cluster.

O'BRIEN, P.T. 1993. Fellowship, Communion, Sharing. (In Hawthorne, G.F., Martin, R.P. \& Reid, D.G., eds. Dictionary of Paul and his Letters. Downers Grove : IVP. p. 293-295.)

PATHRAPANKAL, J. 1995. Apostolic Commitment and "Remembering the Poor". A Study in Gal. 2:10. (In Fornberg, T. \& Hellholm, D., eds. Texts and Contexts. Biblical Texts in their Textual and Situational Contexts. Essays in Honor of Lars Hartman. Oslo : Scandinavian University Press. p. 1001-1018.)

PATO, L.L. 1997. Indigenisation and Liberation. A Challenge to Theology in the Southern African Context. Journal of Theology for Southern Africa, 99: 40-46.

POBEE, J.S. 1993. Africa in search of Identity. (In Reuver, M., Solms, F. \& Huizer, G., eds. The Ecumenical Movement Tomorrow. Suggestions for Approaches and Alternatives. Kampen, Geneva : Kok, WCC. p. 387-398.)

PUNT, J. 2000. Towards constructing Paul's economic vision on work. In die Skriflig, 34(3):1-21.

SCHMIDT, T.E. 1993. Riches and Poverty. (In Hawthorne, G.F., Martin, R.P. \& Reid, D.G., eds. Dictionary of Paul and his Letters. Downers Grove : IVP. p. 826-827.)

SCHRAGE, W. 1988. The Ethics of the New Testament. Trans. Green, D.E. Philadelphia : Fortress.

SIDER, R.J. 1977. Rich Christians in an Age of Hunger. A Biblical Study. London : Hodder \& Stoughton.

TROBISCH, D. 1994. Paul's Letter Collection: Tracing the Origins. Minneapolis : Fortress.

VAN WYK, J.H. 1978. Ethical Principles and Economic Facts. A Theological-Ethical Reflection on the Problem of World Poverty. (In Nürnberger, K., ed. Affluence, Poverty and the Word of God. An Interdisciplinary Study Program of the Missiological Institute Mapumulo. Durban : Lutheran Publishing House. p. 207220.)

VERHEY, A. 1984. The Great Reversal. Ethics and the New Testament. Grand Rapids : Eerdmans.

\section{Key concepts:}

faith and materiality

Jerusalem collection

Paul's vision on poverty

righteousness, fellowship and sharing

\section{Kernbegrippe:}

geldinsameling vir Jerusalem

geloof en die materiële

geregtigheid, gemeensaamheid en mededeelsaamheid

Paulus - siening van armoede 